\title{
URBAN SHRINKAGE AS A CHALLENGE TO LOCAL DEVELOPMENT PLANNING IN SLOVAKIA
}

\author{
Ján BUČEK, Branislav BLEHA
}

\begin{abstract}
The demographic characteristics of "shrinking" processes in large Slovak cities, as well as the awareness of such shrinkage processes in local development planning, is the subject of this article. Population loss, together with other demographic indicators, clearly documents such a trajectory in urban development. In spite of this reality, there is only limited reflection of the "shrinking" in planning documents of cities approved by town councils. Some reasons for this decreased sensitivity to the complex problem of shrinking cities include missing relevant information (e.g. demographic prognoses), the milder forms of "shrinking" in Slovakia, the absence of political acceptance of the process by local elites, and the dominant-growth oriented planning practices.
\end{abstract}

\section{Shrnutí}

\section{Zmenšování měst jako výzva plánování rozvoje na místní úrovni na Slovensku}

Př́spěvek je zaměřen na demografické charakteristiky a míru zohlednění procesů „shrinking“ $v$ plánování lokálního rozvoje ve velkých slovenských městech. Snižování počtu obyvatel spolu s dalšimi demografickými ukazateli jasně indikuji př́tomnost této trajektorie vývoje. Přes realitu zmínèného vývoje nacházíme jen malý odraz „shrinkage“ v plánovacích dokumentech měst, které schvalují městská zastupitelstva. Mezi důvody, které vysvětlují tuto sníženou citlivost na komplexní problém zmenšování měst, můžeme uvést nedostatek relevantních informací (např. demografických prognóz), mírnější podoby „shrinking“ na Slovensku, absenci akceptování tohoto procesu v místních elitách i převládající praxi růstově orientovaného plánování rozvoje měst.

Keywords: shrinkage, large cities, local development, planning, demography, Slovakia

\section{Introduction}

Cities are not only growing but also stagnating or declining. One of the frequently-used conceptual terms related to processes of depopulation, economic and social restructuring and physical environment degradation in urban areas, is shrinking. Urban shrinkage, or the "shrinking city", is usually referred to as an urban area featuring population loss, economic decline and restructuring, increasing unemployment or various kinds of social problems (Rienietz, 2009; MartinezFernandez et al., 2012). It is a multidimensional process with manifold effects, accompanied by simultaneous quantitative and qualitative changes. We can observe its demographic, economic, geographical, social and physical environment dimensions. It is a result of multiple parallel processes having global, national, regional and local dimensions and differences.

The main aim of this contribution is to outline the basic features of the shrinking of Slovak cities, as well as awareness of and responses to these phenomena.
At first, we focus on demographic processes occurring in a selected group of cities during the period from 1996-2010. Demographic development is usually accepted and used as one of the crucial indicators of shrinkage (e.g. Bleha, 2011; Martinez-Fernandez, Weyman, 2012). We also subscribe to views that demographic development and urban shrinking do not depend exclusively on economic development (e.g. Grossmann et al., 2008). Due to the lack of actual direct data at a city level, we avoid far-sighted conclusions concerning economic restructuring, housing stock or infrastructure adaptation aspects of shrinking. Besides the necessary analyses of demographic development in cities, we focus on the reflections of population processes indicating shrinking in the main development planning documents elaborated at a local level in Slovakia. This planning response is among the growing fields of interest within the "shrinking" debate (Pallagst, 2010). It reflects awareness as well as preparedness to respond actively with needed measures and decisions. As Wiechmann (2008) 
appropriately documented in the case of Dresden, planning documents and related policies do not reflect the existing urban development trends immediately but with a certain delay.

In order to provide realistic knowledge, we focused on three major types of development- related documents (programmes and plans for territorial planning, strategic development and social services). As the official documents adopted by the City Council, they serve as the major guidelines for local self-government decision making. They also provide a regulatory and activity framework for many other actors within the cities. Each of these documents contains analytical sections in which we search for the identification of 'shrinking' in the city as a building block for the awareness of 'shrinkage' formation. These plans also contain more implementation and executive based sections, in which we look for shrinking-linked priorities or measures (focusing on the usual fields of shrinking). Our principal attention is paid to strategic development planning documents known in Slovakia as the Programmes of Economic and Social Development. We would like to know if local elites and the public are aware of such development and respond properly, or if they are still under the influence of the growth-oriented stereotypes in approaching their cities' development, underestimating the shrinking of their cities' face. Our main attention concentrated on 11 Programmes of Economic and Social Development (covering each studied city) and 9 Community Plans of Social Services that had already been adopted. In addition, we also evaluated 6 Master Plans that had been adopted or revised within the last decade (up to 2011).

We formed a sample of Slovak cities suitable for our research purposes with the intention of including Slovak "secondary cities" (i.e. not only Bratislava and Košice). Such cities are mentioned as those "outof-sight" but facing serious changes (Grossmann et al. 2008). Cities exceeding the limits of one or two hundred thousand inhabitants are frequently used in international analyses (e.g. Turok, Mykhnenko, 2007). In Slovak geography we can find a frequently-used size limit of 50 thousand inhabitants (e.g. Slavík, Kožuch and Bačík, 2005; Buček, 2005), which determines a group of the largest Slovak cities (among which the two largest cities of Bratislava and Košice have a specific position). They represent nodes of the largest urban functional regions and form altogether (with mutual linkages) the main settlement "skeleton" of the country. Within this group of 11 cities, we find eight cities serving as the seats of regional selfgovernments (including the capital city of Bratislava, with the exception of Martin, Poprad and Prievidza). One should keep in mind that among nearly 2,900 local self-governments in Slovakia, there are 138 cities. The share of the urban population is slightly below $55 \%$ of the total population (2010). A large group of cities has less than 10 thousand inhabitants and some of them even less than 5 thousand inhabitants (resulting from the definition of statutory cities in Slovakia).

The suitable time-span for data in considering urban shrinkage is subject to much discussion. We assume that a longer period with certain internal time space consistency is indispensable. Following this criterion, we primarily focus on the period from 1996-2010. The period is long enough and offers an opportunity to discuss the issue within the latest possible time scale. During this period, no major changes occurred in the composition of this group of cities (one city exceeded the lower size limit in this period - in 2010). As an important feature, we consider also the fact that most administrative changes within the city borders had been completed earlier. This makes it possible to eliminate misleading considerations based on the different spatial delimitation of the cities. Due to the forced integration of neighbouring villages during the socialist period, the cities regained their autonomous position mostly during the first years after 1989. This was of course accompanied by significant changes in population numbers in most of the cities in our sample (except for Bratislava and Košice).

\section{The context of shrinking in Slovakia}

Cities in Central and Eastern Europe are often considered as typical cases of urban shrinkage. As revealed in many studies (e.g. Turok and Mykhnenko, 2007; Steinführer and Haase, 2007; Grossmann et al., 2008), population decline in cities is a common phenomenon in this region. It is influenced by a range of processes accompanying the post-socialist transformation and globalisation. Nevertheless, more detailed information on shrinking in various Central Eastern European countries is often missing. More attention is paid to developments in Poland and the Czech Republic (e.g. Steinführer et al., 2010; Rumpel and Slach, 2012), while Slovakia belongs to a group of less systematically covered countries.

Among the few Slovak authors dealing with urban shrinking, Finka and Petríková (2006) have provided some introductory knowledge within the CEE context. Slavík, Kožuch and Bačík (2005) mentioned the shrinkage indirectly in their evaluation of population development and suburbanization in cities since 1990. Bleha and Buček (2010) focused on selected local population and social policy features of shrinking with the example of Bratislava that represents a very suitable observational unit for such 
an analysis. Bleha (2011) analyzed local population policy and shrinkage perception among mayors in Slovakia - likely the first information on local decisionmakers' perceptions of the current demographic changes and their implications. Finally, Buček and Bleha (2012) outlined shrinkage in urban planning in an introductory essay. It is worth mentioning that urban shrinkage provides an additional perspective for various more detailed analyses.

The Slovak urban system had experienced decades of permanent growth (in population, as well as in spatial and physical terms), which culminated during the 1970s and 1980s. Due to the combination of socialist industrialization and urbanization, the decades of growth were followed by population decrease in Slovak cities after 1989. At the beginning of the transition period, a sudden population decrease related to changes in administrative borders of some cities. Consequences of the post-socialist transformation accompanied by radical economic and social reforms represented other general reasons. Economic downturn and social uncertainty influenced population processes, including family and migration behaviours. The collapse of many industrial enterprises led to wide-scale deindustrialization. Together with the collapse of new housing construction, it stopped immigration to cities for years. The new service-based economy in cities was growing slowly and only in some of them. Delayed a few years, suburbanization started to be influential in the largest cities.

In the $1990 \mathrm{~s}$, a wide debate related to population development in cities was still missing, despite the availability of indicators revealing changes in population development. This can be explained by common expectations that after the temporary postsocialist social and economic decline, the dynamics of growth would be re-established and the cities would grow further. The population decrease in the cities was considered as temporary and the phenomenon was denoted as a stagnation of their size. However, the processes of population decrease remained a dominant feature of development in most large cities for a longer period. Some newly-emerged cities lost more than $10 \%$ of their population within 15 years after 1996 (mostly smaller cities dependent on an industrial tradition). Now, having the possibility of evaluating more than twenty years of post-socialist urban development, we can observe no significant return to growth in the cities. The attention to the processes of shrinking in Slovakia is under such circumstances a great challenge. A cardinal issue is, however, whether the local elites and the policy makers are aware of such a development and to what extent they have adapted their approaches to development in this respect.
It is important to mention that there has not been any explicit national urban policy (or a specific policy focusing on the problems of shrinking cities) in Slovakia. We can only find specificallyoriented measures adopted by the state (including allocated resources) in which cities play decisive implementation roles (see e.g. Buček, 2005). The most important aspect is that the central state has formulated a programming and planning framework within which the issue of shrinking can be addressed. State ministries have also managed to elaborate nationwide development planning documents and strategies (e.g. in regional development, territorial planning, environmental planning, population forecasts). However, most of the nation-wide planning and forecasting documents are of older date (adopted at the beginning of the previous decade) and need to be revised (we can expect such revisions within the forthcoming years). They do not pay much attention to the issue of shrinking (although the indices of population development in cities are mentioned). Slovak central state spatially-oriented policies are more focused on regional development policy and the mitigation of regional disparities. Also, the wide-scale decentralization in the last decade resulted in urban problems being perceived primarily as problems of individual local self-governments.

\section{Demographic identification of shrinking in Slovak cities}

The demographic data document what we can observe as a crucial turn in the natural increase and migration flows of population in Slovakia after 1989. In this section, we demonstrate to what extent this applies to the largest Slovak cities. We compare the population development among them, compared to rural settlements, as well as within the framework of total population development in Slovakia. Our main intention is to identify to what extent we can consider changes in the population development in cities as relevant cases of urban shrinkage. After arguments confirming such a development, we present the main features and factors related to this development. Table 1 provides a list of the studied cities ordered by their population sizes. Because a problem exists with data reliability before 1996 (due to the abovementioned disintegration processes that cities experienced in that period, see e.g. Slavík, 1998), we used indicators of population change and age structure in the period since 1996.

The decrease of reproduction dynamics is linked to the decline of the total fertility rate after 1989. It was recorded very soon and at first especially in the largest cities. The trend is based on the phenomenon 


\begin{tabular}{|l|c|c|c|}
\hline \multicolumn{1}{|c|}{ City } & $\begin{array}{c}\text { Population number } \\
\text { (as of Dec. 31st 1996) }\end{array}$ & $\begin{array}{c}\text { Population number } \\
\text { (as of Dec. 31st 2010) }\end{array}$ & $\begin{array}{c}\text { Relative change } \\
\text { (in \%) }\end{array}$ \\
\hline Bratislava & 452,288 & 432,801 & -4.5 \\
\hline Košice & 241,606 & 233,886 & -3.3 \\
\hline Prešov & 93,147 & 91,193 & -2.1 \\
\hline Žilina & 86,811 & 85,129 & -2.0 \\
\hline Nitra & 87,569 & 83,444 & -4.9 \\
\hline Banská Bystrica & 85,052 & 79,819 & -6.6 \\
\hline Trnava & 70,202 & 67,368 & -4.2 \\
\hline Martin & 60,917 & 57,987 & -5.1 \\
\hline Trenčín & 59,039 & 56,403 & -4.7 \\
\hline Poprad & 55,303 & 54,271 & -1.9 \\
\hline Prievidza & 57,395 & 49,994 & -14.8 \\
\hline Slovakia & $\mathbf{5 , 3 7 8 , 9 3 2}$ & $\mathbf{5 , 4 3 5 , 2 7 3}$ & $\mathbf{1 . 0}$ \\
\hline
\end{tabular}

Tab. 1: Population size of the largest Slovak cities

Source: Statistical Office of the Slovak Republic (1996-2010)

of postponed fertility, which is extensively debated in post-socialist transition countries. The total fertility rate in the largest Slovak cities is well below 1.3 now. This indicates that it is below the level considered as the lowest low fertility value - the term first introduced by Kohler et al. (2002). Its values for Bratislava and Nitra were 1.15 and 1.0 respectively in 2007 . A few years ago, this value had been less than 1 in a number of cities. Although we can see a gradual recuperation of births (primarily in Bratislava), this extremely low fertility results in the low number of births regardless of the numerous reproductive cohorts of the 1970s. At the same time, despite growing life expectancy, the natural increase is close to zero - although some signs of growth are evident for the years 2008-2009 (see Fig. 1). However, the changes in fertility and age composition are leading factors of changes in natural decrease and the weight of mortality is expected to increase in the coming years.

Development in the capital city of Bratislava was less positive. However, since the year 2006 we can observe the expansion of postponed births there. The dynamics of crude birth rate and crude mortality rate are also influenced by the so-called age-structure momentum - the age structure of cities is considerably unbalanced as a result of unstable and intervening socialist migration. The natural increase either diminished or turned into decrease later from higher levels in the smaller cities of Poprad and Prešov, located in the traditionally more conservative eastern Slovakia. We can summarise that the natural movement of population is not a principal cause of urban shrinkage in the monitored group of the largest Slovak cities. This is true despite the varying values, their changes and the heterogeneity of this sample of cities, especially during the first half of the observed period. These cities gained 1-4 inhabitants annually (calculated per one thousand inhabitants), due to a birth rate that was higher than the mortality rate. Mortality will increase in the future in relation to the increasing number of elderly people, despite the growing quality of life and the above-average life expectancy in these cities. According to Šprocha (2008), life expectancy of men in Bratislava was 73.07 years (2004-2007). In the centres of regional self-government it was 72.76 years, while for all cities in Slovakia it was 71.45 years (for Slovakia it was 70.35 years). Similar differences are also recorded for the female population. Such a demographic paradox will also affect the birth rate. Although an increased total fertility rate is expected, the cohorts of women at reproduction age will be significantly diminishing, resulting in a decrease of births. Not-surprisingly, such a trajectory is expected in most Slovak regions according to the authors of the sub-national population development forecast (Bleha and Vaňo, 2008).

A different view is offered in Fig. 2, which represents net migration. Almost all cities showed a population loss as a result of higher out-migration during the analyzed period. The population losses were increasing each year after 2000, although in some cities the figures improved around the year 2005 due to a better economic cycle period. The main reason for such a development in most of the cities is residential suburbanization. While the suburbanization before the year 2000 had been limited, it expanded later, reflecting the improved social and economic situation and partly also the increased prices of housing in the cities. Negative annual rates exceeded ten per one thousand inhabitants in some years (e.g. for the city of Prievidza). 


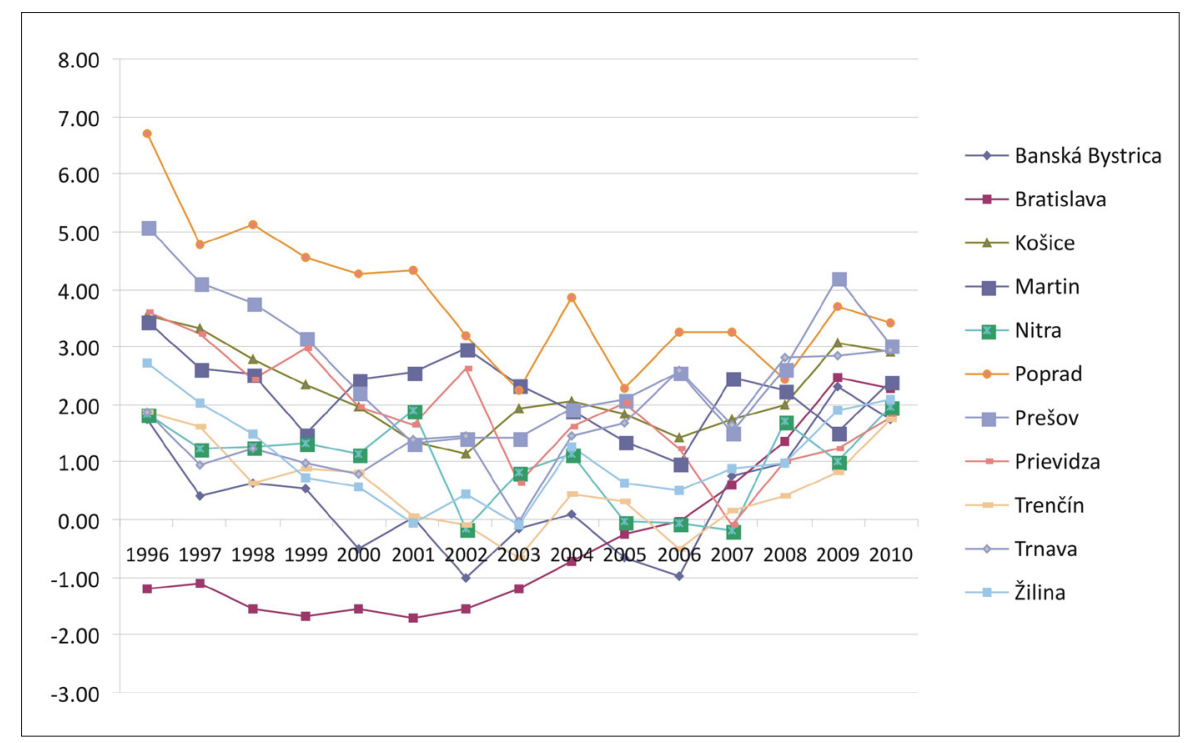

Fig. 1: Natural increase/decrease (per thousand inhabitants)

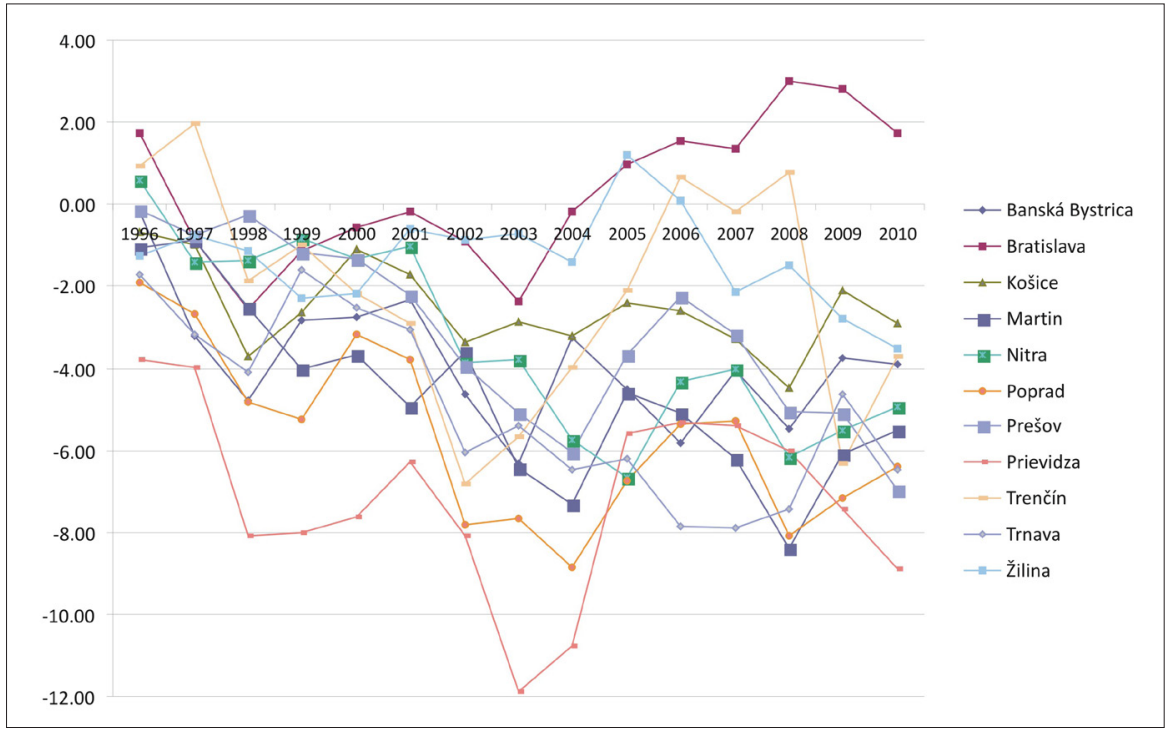

Fig. 2: Net migration (per thousand inhabitants)

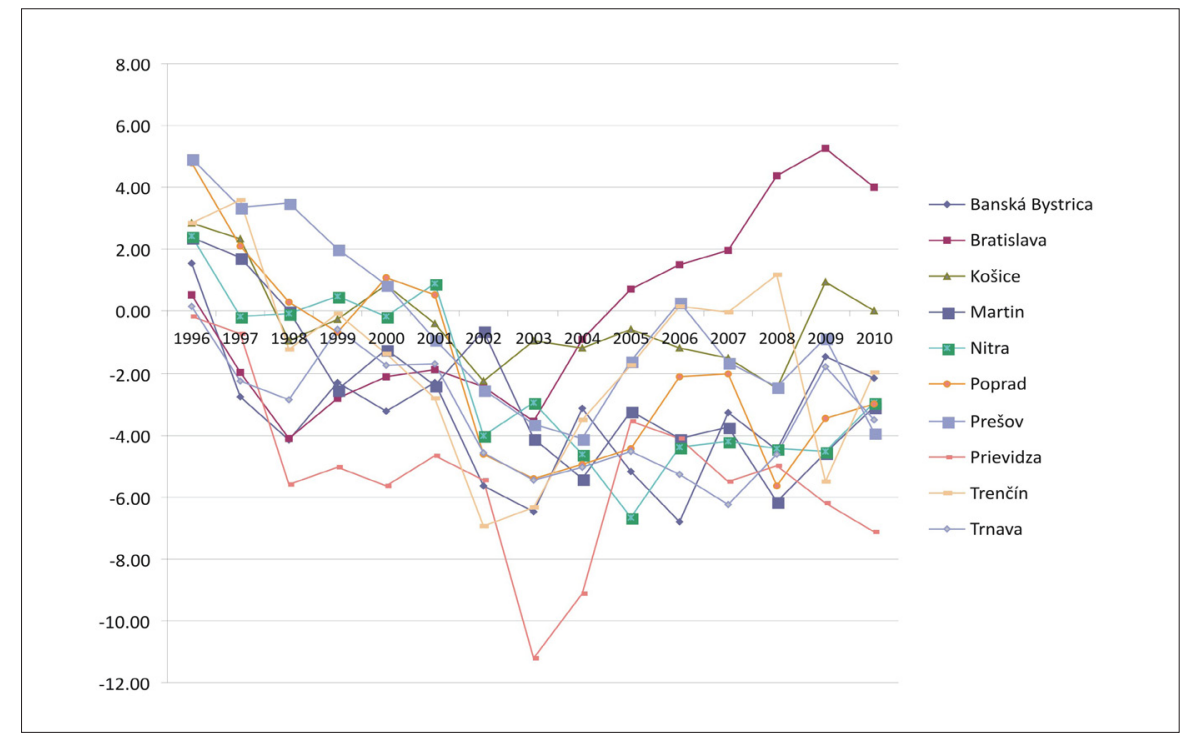

Fig. 3: Annual population increase/decrease (per thousand inhabitants) 
The waning of suburbanisation and its lower intensity appeared at first in Bratislava. A turn back to positive numbers was in this case connected with new immigration tendencies, decisions to live closer to the place of work and with the expansion of new housing development in the city (at the end of the decade, the new housing development balanced out-migration also in other cities). The labour market in Bratislava was the biggest and the least saturated in Slovakia. The analysis published by Jurčová et al. (2006) shows that while the communities below 5,000 inhabitants were losing population and the cities with more than 20 thousand inhabitants were gaining most until the year 1993, the situation reversed after this year totally (as documented in Fig. 2). A deeper evaluation of the migration data shows that inhabitants of these cities move especially to communities in their close hinterland. Understandably, the largest belt of such communities is in the Bratislava surroundings. Only in a few cases of the observed cities, is this out-migration linked to worse social and economic situations.

The overall situation is presented in Fig. 3, focusing on total population change. It is clear that the annual total decrease of population is caused by a negative migration balance, although moderated by natural increase. Population development is more different in the case of Bratislava, thanks to the positive population development in migration and natural increase since 2006.

The development shows a population decrease presented in Fig. 4. All large cities lost between 1.9 to $12.9 \%$ of their populations in the period from 1996-2010. Prievidza as the smallest city in the sample, faced the most negative population change. However, in this case, important factors besides the population development are industrial restructuring (the city and the surrounding region used to be a traditional centre of mining, energy production and heavy chemistry) and less favourable transport position (outside the main motorway and railway lines). In general, we can conclude that these population losses are quite significant. A similar situation is evident in the whole group of Slovak cities in comparison to rural settlements. While the cities have a positive natural increase, rural settlements have a negative natural increase. In terms of migration, the situation is reversed.

Besides the population dynamics it is important to analyze the age structure in cities (Fig. 5). An increase in mean age is recorded in all eleven cities in the period 1998-2010. The greatest increase is recorded in Poprad and namely in Prievidza, in which the mean age increased by about $19 \%$. The ageing index in this city increased more than 2.5 times - from 50 to 133 inhabitants 65 years and older per 100 inhabitants aged 0-14 years. In Bratislava, this index increased by more than three quarters, while Slovakia as a whole exhibited growth by 60 per cent. The mean age is higher in the observed cities comparing to the Slovak average, with the exception of the cities of Poprad and Prešov in Eastern Slovakia. The population in all Slovak cities is ageing substantially faster than the rural population.

We can summarize that from the demographic point of view, we observe urban shrinkage in Slovakia. The number of inhabitants is diminishing in most of the 138 cities. The number of persons living in the cities has decreased by almost 100 thousand. Approximately half of the urban population loss is caused by developments in the eleven largest Slovak cities. However, this group of cities is very heterogeneous in terms of population dynamics. A substantial influence on this decrease is the redistribution of population from cities to rural settlements.

The scale of the population loss in cities cannot be considered as devastating, but it calls for attention. As a certain positive feature, we can consider the fact that most of the emigrants live in the urban functional regions of their respective cities.

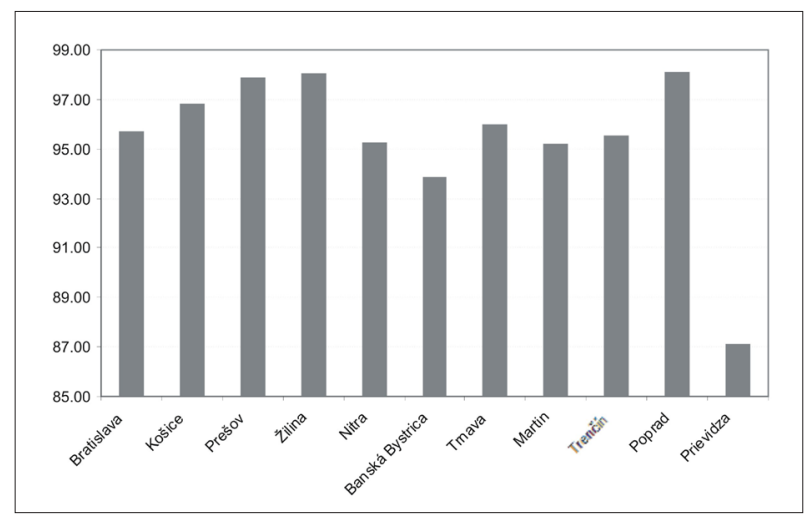

Fig. 4: Index of population growth in the period from $1996-2010(1996=100)$

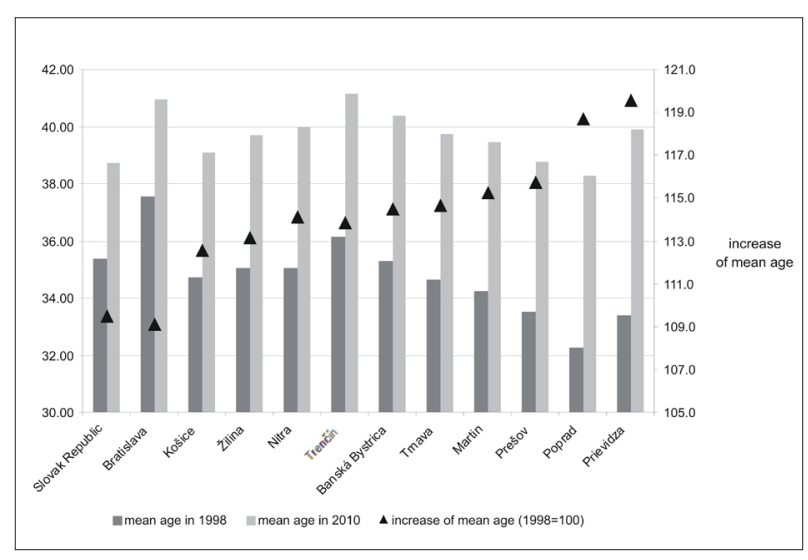

Fig. 5: Mean age of population 
Among the most serious issues related to current trends and the scale of shrinking in Slovakia is population ageing. Taking into account predicted doubled numbers of seniors in the Slovak cities within the next twothree decades this really becomes a serious problem. It is an issue that concerns both urban and rural environments. Nevertheless, while the rural population recorded a higher mean age in 1996, the situation turned in 2004 and the urban population became older. This caused a three times faster increase of mean age in urban populations comparing to rural populations during the last 15 years. Although it is more a result of the age structural momentum, i.e. transition of big cohorts to post-productive age and larger decrease of fertility in cities, to a certain extent it is also affected by suburbanization. The mean age in our selected cities is growing much faster comparing to the total Slovak population, with the exception of Bratislava. The most affected city from the viewpoint of shrinkage and ageing is the smallest city in our sample - Prievidza. As already outlined, this city has faced serious economic restructuring, combined with a less favourable transit position and diminishing role as a traditional housing centre for the surrounding region.

\section{Reflection of demographic base of shrinking in major urban development documents}

Planning at the local level has a long-lasting tradition in Slovakia, but for decades there were mostly only territorial plans adopted (the most important were Master Plans). The role of planning has been strengthened step-by-step in the last two decades. Local self-governments have obtained many new powers and responsibilities, accompanied by pressure upon improving management practices. They are responsible for managing local development, provision of local services, quality of the environment, etc. For these purposes, new kinds of development planning documents and practices have been introduced. Besides the territorial planning-based documents, there are documents prepared in the field of strategic development planning, as well as planning documents addressing particular specific fields of activity. We focus on three selected local development planning documents that provide the main framework for managing city development. We assume that they also should reflect processes of shrinking following their primary demographic identification. The elaboration of these documents is obligatory for each Slovak city, according to legislation, and they have to be adopted by City Councils. While Master Plans are strongly expert-dominated, the other two kinds of local development documents are more participatory and community-based documents. Unfortunately these planning documents in cities do not fulfil satisfactorily the expectation to identify processes of shrinkage as expressed in demographic development. Demographic analyses and projections of some cities' populations are more "wishes" or "imaginations" of their local self-governments than realistic demographic futures. As we document in the following discussion, it is caused predominantly by less elaborated demographic forecasts that suffer from a simplified, schematic approach, a short-term analytical basis, and spatial incompatibility.

Territorial planning has the longest tradition among local planning activities, which leads to the adoption of a Master Plan (in Slovak - Územný Plán - UPN). In its current form it is elaborated according to legislation adopted already in the mid-seventies (Act No. 50/1976), but with many "modernisation" amendments adopted within the last twenty years (see e.g. Slavík and Kožuch, 2003). It represents a crucial local development regulatory document with a strong focus on land use, construction and development limits. Its elaboration is a long-term, procedurally complicated and costly process. Its selected sections are adopted as local by-laws.

The second type of planning at the local level is in line with the growing attention to regional development. Its role is growing since the decentralization of powers and resources for the local level introduced into practice by stages since 2002 . This kind of local planning was introduced at the beginning of the previous decade (Act No. 503/2001 on the Support of Regional Development, later amended) and is leading to the elaboration of the Programme of Economic and Social Development (in Slovak - Program hospodárskeho a sociálneho rozvoja - PHSR). It bears typical signs of strategic development planning at the local level (e.g. Buček, 2007). The last type of planning document focuses in more detail on the planning of social services. It was introduced by legislation in 2008 and it is directly related to the transfer of more powers in social services to the local level (Act No. 448/2008). The output is a Community Plan of Social Services (in Slovak - Komunitný plán sociálnych služieb - KPSS). Both of these plans are prepared within a shorter time frame than the Master Plan. They are more implementation-oriented, including concrete measures and financing of selected activities. In order to recognise to what extent these documents identified the demographic base of shrinking, in the following we focus on the "demographic parts" of their analytical sections.

Programmes of Economic and Social Development (PHSR) are prepared for a normal time span from 7 to 15 years. All of the analyzed PHSR were adopted or amended after the year 2005. Currently 
valid PHSR have worked with time frames up to 2013, 2015 and 2020 (depending on the time of adoption). In each of these programmes we can find two basic sections - analytical and programming, linked together by the vision of future development. The analytical section should contain a demographic development analysis with more details concerning the latest trends. We can conclude that each of the 11 cities programmes contains a demographic analysis, which is in principle at a sufficient quality. It includes an overview of basic indicators of demographic dynamics and structures. However, due to the prospective character of the programmes, a more important part is their population forecast section. From this point of view, we found less satisfactory elaborated outcomes. Within the strategic planning documents of all 11 cities only three had a demographic forecast elaborated at an adequate level, based on the application of the cohortcomponent method, with a sufficient explanation of introductory assumptions, accompanied by the transparent and logical presentation of results. On the other hand, a positive feature is that the demographic forecast was missing in any form only in one city.

Although most strategic plans are prepared within the time framework up to 2013-2015, forecasts are calculated for a longer period, mostly up to 2020 2025. These less elaborated forecasts suffer from simplicity and a schematic approach, not to mention inconsistent assumptions. For example, we can find simple extrapolations of total population size, or attempts to derive a future population number from the official forecast of population number prepared for larger territorial units, mostly districts. An unclear proposal of future age structure on a basis of more or less contradictory assumptions, without a declared calculation method, we consider as the worst case. In some cities, these less elaborated forecasts are too optimistic in forecasting the already existing and future population size development. The population number is substantially higher in forecasts already 4-5 years after their adoption, compared to the known actual population size. The reason for unsatisfactory demographic forecasting in strategic plans is definitely the fact that it is a sophisticated sub-discipline of demography. Authors/participants working on strategic plans usually are not experts primarily in this field. There also are no standards defined in general planning guidelines requiring the application of more reliable forecasting methods. It also is a matter of fact that more qualified planning would be more costly for local budgets financing their elaboration.

Stipulated by legislation, the Community Plan of Social Services requires analyses of social and demographic data with reference to the city territory.
Ten of eleven cities in our sample already had adopted KPSS (with the exception of Bratislava). Current legislation does not define precisely the scope of analyses, so it is upon the decision of local selfgovernment bodies and those that directly elaborate this plan. Usually the crucial part of the KPSS is an analysis of social services and needed facilities, as well as their financing. Quite often a survey of citizens' and clients' satisfaction is included. Demographic analyses are in most cases inadequate. We found cases in which the analysis of demographic data works only with one or two year population data (number, mean age, births/deaths, in and out-migration), having only a basic indicative reason. Any longer-term population forecasts are missing in most of them, although the time framework of the plan is about $4-5$ years. As a result, only general remarks on ageing and pressures on the traditional family are mentioned, and the expected pressure on local finances is indicated. A more specific calculation of future needs is hardly possible under such state of analysis. Only a few cities have more extensive analyses (longer time series, more indicators), including a demographic "outlook" or a simple population forecast (for example derived from the official forecasts at the district level). Nevertheless, it made it possible to outline a basic trend in the population development. It concerned mostly the rapidly growing share of elderly people and services they will need in the future. In most cases, an explicit formulation of conclusions based on demographic analyses is missing. This section seems to include more KPSSs probably with an ambition to fulfil legal obligations, but it does not serve as a base for planning the provision of efficient future social services.

The analyzed Master Plans (UPN) typically feature good quality demographic analysis. Especially the latest UPNs have a realistic vision of population development that incorporates the stagnation of population size. It results from a more professional approach and longer experience in their elaboration. The principal participants in their elaboration are specialised planning companies which often have their own demographers or invite external specialists for demographic analyses (from universities, research bodies). The good quality of the analysis of demographic processes and structures is, however, usually not combined with a good demographic forecast. In some cases, simple extrapolations and estimation are used with an absence of more variants. As a result, an unrealistic population growth is still expected in most cities. It is already clear (due to the longer time of Master Plans elaboration), that these earlier forecasts are in conflict with the already documented population size of cities. 


\section{5. "Shrinkage"- based responses and measures in major urban planning documents}

As often mentioned, shrinkage brings new challenges to urban planning. According to the already existing debate on the interaction of shrinking and planning in cities, we can turn attention to a known set of primary issues (Wiechmann, 2008; Hollander et al., 2009). One of the most challenging is the planning of housing and housing stock adaptation (e.g. including demolition) and related housing market tensions (e.g. Bernt, 2009). Longer term shrinking also generates large areas of vacant, derelict, functionally obsolete land, mostly linked to processes of deindustrialisation. It results in a greater attention to the issue of land use in such cities. It is accompanied by manifold environmental aspects and change in the urban landscape. Vacant land and emptying housing estates also can lead to overcapacity in the urban infrastructure (see e.g. Moss, 2008) and problems with the effectiveness of services delivered (water, gas, heating etc.). A similar pressure is experienced by social infrastructure conceived on a wider scale school networks, cultural centres, health facilities. Shrinking has important consequences for the provision of local social services.

This development places on the agenda a wider issue of infrastructure right-sizing. All these issues acquire a new and complicated dimension when linked to local finances. Any demographic change has its own fiscal implications (see e.g. Wolf and Amirkhanyan, 2010). Decrease of income generated by property taxes, shared taxes, or user fees can substantially undermine standards of local services and the potential of local government. Among emerging questions (Hollander et al., 2009) we can also find how to cope with social equity and urban density issues in a shrinking city. We focus on goals and measures in planning documents from the point of view of their responsiveness to accustomed processes of shrinking in Slovak cities. In our sample of Slovak cities, we searched for an explicit expression of goals reflecting different needs of shrinking cities. We also tried to identify concrete measures that would confirm active adaptation of cities to shrinking in the afore-mentioned fields of land use, housing, infrastructure (social, technical), economic restructuring, fiscal policy and social issues.

One of the most visible linkages to shrinking processes concerns land use in Slovakia. Particular attention is related to deindustrialisation and its consequences. Large areas of former industrial plants are now vacant and not used in cities. While those areas close to the city centre are often already restructured to new functions, large sites of unused and derelict land have remained inside the compact urban environment. Some cities attempt to revitalize them and offer them as brown-field locations. For example, the city of Banská Bystrica intends to provide such land with a specific regime and support, to adapt it quickly into new use. A precise identification of such lands and plans to elaborate specific projects for their future use is declared in many cities. At the same time, new industrial locations (industrial parks) are prepared as 'green field' or land for such use is reserved in UPN. An interest is usually expressed to attract new developers that will generate new jobs. In many cases, a hope in some new investments inflow is ground for calculated future growth, despite the awareness of existing development difficulties. In more cases, we can find intention for more efficient land use within an already built-up area, following the concept of a compact city. Objectives are often formulated of new developments within an already existing area of the city, using available vacant land, with preference given to compact forms, e.g. in housing construction (e.g. Nitra).

Housing is not considered as a challenging issue from the viewpoint of Slovak cities. After the large-scale housing privatisation, most housing is private and the housing issue is considered to be the direct responsibility of citizens. The central state and the local selfgovernment are responsible for a general framework, including various forms of housing development support in general (mortgages, land availability). However, due to extensive housing stock in mass concrete socialist housing estates on their territory, most cities point out a need for their regeneration, modernization or efficiency improvement. They are interested in the humanization of the housing estates living environment to prevent losses and degradation of this housing stock. Humanization (a term close to the meaning of more widely-used regeneration, mostly used in the Central Eastern European context, e.g. in Slovakia, Czech Republic and Poland) emphasizes a need to respect the human dimension and quality of the living environment, not developed during the socialist period (e.g. Gajdoš, 2002). As a result, great efforts have been addressed, for example, in public spaces improvement (pedestrian ways, street lighting, playgrounds, cycling routes, more green spaces) in old housing estates.

All cities must also consider extensive new housing construction, which is also demanded by citizens. These needs are partly explained by the expected pressure for improvement of housing standards and changes in the composition of households (with the increasing number of small households). The risk of this too optimistic perception of development is mitigated by 
minor direct involvement of local self-governments in housing provision and real estate market supplydemand development. Most cities expressed a need of further activity in the field of social rented housing. An inevitable direct involvement of the public sector will focus mostly on housing for vulnerable groups of citizens. Some cities announced the elaboration of their own Housing Strategy for the future (in rare cases already adopted). Cities can use for their activities in social housing support provided by the central state Housing Support State Fund. It is clear that the development in housing is less dramatic than in certain East German cities. The shortage of housing resources in cities played an important role, namely in the 1990s and in the first half of the next decade, as economic recession limited new housing construction and the absence of housing support tools. Nevertheless, based on the exaggerated population growth forecast, some extensive new housing construction locations may be reconsidered.

The most typical powers for which local selfgovernments are responsible is pre-school and school education network management. Also in the field of school facilities, the construction of new schools is envisaged, these being planned in newly developing areas. No details are specified about what will happen to the already existing schools. In the city of Prešov, a need has been already suggested to close some school facilities, e.g. in the city centre, and to change the function of these buildings in response to the changing composition of households. The need to close some schools is clearly possible. One of the typical cases of functional conversion is a transfer of some primary and secondary schools to expanding universities, or their transformation into old people's homes.

For technical infrastructure a 'growth-based' approach is still in evidence. Plans are focused mostly on infrastructure needs in areas of new development, replacement of older infrastructure and completion of missing environmental infrastructure (sewage system, water treatment). No attention is paid to overcapacity, although it already exists. Growthbased thinking expresses its perception as reserves (for further development) and good future potential. Nevertheless, some cities have declared the effort for efficient infrastructure management, e.g. in water and sewage system. There are Master Plans that formulate future needs according to the forecasted higher number of population. For example, the need of water infrastructure capacity for the city of Trenčín is calculated for an unrealistic 75,000 inhabitants in 2015 (a contradiction to the later adopted PHSR, which indicates more realistic 59 thousand inhabitants only).
Programmes of Economic and Social Development usually contain analyses of local self-government finance (such analyses are not in the other two plans), in some cases combined with analyses into availability of other resources for development. The important source of local finance is personal income tax as shared tax (about 70 per cent of its total yield is distributed to local self-governments in Slovakia). It is distributed namely on the basis of the number of permanently registered local residents (official number being provided every year by the Statistical Office of the Slovak Republic). Changes in population numbers are immediately reflected in the size of funds transferred from this tax to local budgets. Similar negative financial effects have the changed population numbers in the individual groups of inhabitants, for example, in the number of pupils in local schools. The transfer of resources from the state budget for education is calculated predominantly on a per pupil base, so the decreasing number of pupils means less resources for the local education network. This may cause a financial pressure in the network of existing school facilities. Each decrease in the population number means a financial loss for the local self-government and a threat to the public services it provides. A smaller number of citizens means reduced resources provided by fewer citizens as fees for the provision of local services (e.g. waste collection and disposal). It influences the effectiveness of service provision. On the other hand, the PHSR as well as the KPSS should contain measures including their financing scheme. From this point of view some cities indicated a lack of resources to cope with certain urban shrinkage-based issues, such as the regeneration of old industrial land or investments into social services, e.g. for old people. Despite certain logical links, explicit references to shrinkage are missing in the local finance sections of PHSR.

Even a well-elaborated demographic forecast included into the analytical sections of development plans is selforiented if it does not link with the implementationoriented part of the strategy and if it is not transformed into the hierarchy of goals, policies and tools. This is true even though various features in population development (ageing, migration loss) are mentioned as weaknesses or threats (e.g. Prievidza) within their SWOT analyses. This aspect represents unfortunately a weak point of the analyzed strategic plans. Cities have not explicitly defined any strategy reflecting population development trends. Besides direct interventions into the population development (for example steps in attracting new, young inhabitants, efforts to stop outmigration), the agenda of adaptation measures is very important. Proposals that could be helpful from this point of view are mostly missing. It would be useful to have forecasts for the number of elderly people to 
plan measures in social care affairs. The forecasted number of children is very practical for planning future school network policy. Strategic plans (PHSR) prefer orientation on more extensively conceived human and social capital, workforce resources. General statements are often presented that are not directly linked to actual or predicted demographic developments. Thus, the problem has to do with the quality of analyses and forecasts, as well as with the understanding of possible direct and logical links to programming/implementation sections of development programmes. Nevertheless, we can find some positive exemptions that link a good demographic analysis and forecast with adopted measures.

Due to its orientation on social services we concentrated on this set of issues as they were addressed primarily within the Community Plans of Social Services. We recognise both ends of the age structure as relevant to the processes of shrinking. This is why we searched in KPSS for responses focusing on development concerning these two target groups - the elderly population and activities towards families with children (or families in crisis, as pointed out in some KPSS). Within the KPSSs, much more attention has been paid to the elderly population as an immediate challenge for the local selfgovernment responsible for their care in much larger numbers than before. Cities often claimed insufficient capacities and the lack of diversity in providing services for the elderly population. Many of them mentioned unfavourable demographic development as a threat to local social services. All cities reflected an immediate need to increase capacities. To reduce waiting lists to various facilities serving elderly citizens in their cities is cited as an immediate need. Mid-term perspective appeared only in a few cities. They proposed an increase of capacities in certain facilities by about 10-20 per cent within two to three years (e.g. Poprad). Despite the unclear demographic analyses, they also attempted to declare needs concerning their facilities (especially in old people's homes) at a perspective of $4-5$ years, mostly as estimates. We can find conversion plans from facilities serving children to facilities serving elderly citizens (e.g. Martin). Needs were mentioned to invest into the construction of new facilities for old people (e.g. Trenčín, Martin, Košice). Most of the plans avoided outlining of longer-term needs. Nevertheless, the city of Banská Bystrica declared, for example, the need to increase the capacity for elderly care in their households during $2008-2015$ by 50 per cent. As a part of the future solution to meet the growing requirements of care for old people, Košice and Prešov plan to develop their own "City of the Third Age". In rare cases, cities defined also the housing needs according to more precisely identified target groups, including elderly citizens.
We were also interested if there were any signs of the pro-active family policy that could potentially improve development by means of children and family-oriented measures. However, they were mostly oriented to the prevention of family crises, on helping families with handicapped children, etc. Shrinking cities usually face an age imbalance typically by insufficient capacities for old people, and they face less obstacles with the declining number of children (not mentioning overcapacity in some facilities).

\section{Conclusions}

The basic demographic analysis has confirmed shrinking in Slovak cities. However, in their planning documents, this development is less precisely and rarely perceived. Low attention to shrinking in Slovakia has more reasons (besides missing a suitable direct translation of the term "shrinkage" into the Slovak language). Its scale is smaller and it has a less complex character (for example, compared to Eastern Germany). Larger cities do not face deep troubles. Extreme cases of shrinking that would attract the attention of experts, media, politicians and public are missing. The debate on shrinking has also been weakened by strongly dominant transitional and transformation research theorizing during the last two decades. This widely applied framework is weakening in Slovak social sciences only in recent years. It slowly opens space for new concepts in urban development. Shrinking has a potential to be one of the influential emerging approaches linked to the post-transformation period.

There is a contradiction between the general tendency of population stagnation (and population decrease forecasted for the next years) at the national level (see Bleha and Vaňo, 2007) and the locally-expected growth in individual cities. Surprisingly, in their development plans, cities take into account neither the known population development in Slovakia in general (debated extensively, for example, also by the media) nor their own known basic local population trends (the latest population development data are easily available). We can conclude that the missing awareness of shrinkage in Slovakia results from the less precise perception of population development at the local level and its link to nationwide population development. The absence of well-elaborated demographic analyses and especially demographic forecasts influences the less developed public responses to urban shrinkage. It is also caused by the absence of longer-term and deep analyses of urban system development in Slovakia within the last twenty years. Although the urban problems are paid considerable attention (well documented, for example, in Matlovič et al., 2009), any concentration on the 
various partial processes leave to one side deeper urban system development analysis.

Despite the absence of an explicit shrinkage debate, we identified several measures addressing processes linked to shrinking in Slovakia. Cities are particularly aware of industrial restructuring and land use changes, socialist housing estates adaptations, new needs in social service provision, school network revision, not to mention financial problems. Responding to shrinking processes has been unintentional, without any reference to this concept. It also means partial solutions, adopted only in a few cities. The existence of cities that are conscious of these issues can support rising and more complex awareness of these issues in a larger number of cities in the future. In practice, the most typical shrinking-induced decisions are adopted within the framework of so-called "optimization of schools network". For example, in 2004-2005 four schools were cancelled in the city of Prešov and in 2010 there was expected overcapacity of about 1,500 places in these schools. It means again a challenge to close two or three of the currently existing schools. The city of Košice cancelled four schools in 2008, Banská Bystrica two schools in 2012. After the transfer of competences, the cities carefully considered the correct size of their facilities. The latest pressure for adaptation initiated a financial and economic crisis, accompanied with lower resources available in local budgets.

The adopted decisions addressing 'shrinkage' are mostly outside of the main planning documents conclusions. They are the results of current developments, especially the operative evaluations/audits and financial pressures. It means that plans do not serve all real needs and their sense remains unfulfilled to a certain extent. They are "development" plans, which do not address extensively the situation of no-development or shrinking. One possible explanation points to the political nature of the local planning and programming documents. The Programmes of Social and Economic Development as well as the Master Plans are sensitive documents adopted by City Councils. There is an understandable effort to manifest positive expectations and to underemphasize partial less positive local development processes. The local elites seem less anxious to present to the public negative variants of the future or to include less popular future measures. There is a need to strengthen a more expert and professional base of plans against the political pressures. The plans should be more realistic and should provide a more balanced perception of the future.

In general, the Slovak planning system offers an acceptable framework to address the processes of shrinkage. Sufficient reflection in practice has not been attained because of a varied quality of the elaboration of local plans (at least in their specific sections).We can observe an introductory period of neglecting the shrinkage, which is accompanied by its less systematic reflection in local planning documents. Such a delay is in line with the similar development in some other countries (e.g. in Germany, Wiechmann, 2008). The quality of analytical works has substantially influenced the formulation of adequate measures. We can only hardly expect more attention to shrinking if it is not sufficiently identified. One might ask whether even well-identified shrinking processes would lead to reasonable planning-based responses. Perhaps the quality of local planning could improve better developed linkages among these plans (e.g. good population forecasts could improve quality of all plans). Shrinkage is considered as a serious challenge for urban planning all around the world (e.g. Rieniets, 2009; Pallagst, 2010; Wiechmann and Pallagst, 2012) and this is also true for planning practices in Slovakia.

The situation of planning social services that was introduced only a few years ago is quite specific. The good intentions of the legislation have not yet been sufficiently met. We assumed that this plan should reflect a strong influence of demographic processes typical for shrinking, as well as measures to cope successfully with them. Our insight into the already available KPSS indicated less attention to population development. Until now, they are primarily oriented to analyses of the existing situation and identification of immediate shortcomings in the provision of local social services. With rare exceptions, they are not elaborated extensively as documents formulating measures in the mid- and long-term perspective. It is evident that they are the first experiences with planning in the field of social services for local self-governments. They serve particularly for "understanding and mapping" the situation, identification of the scope of short-term tasks and mobilisation of local capacities in this field. They were elaborated during the first years after national legislation had been adopted, without any previous practice. The composition of the quite large teams that worked in this area needs some adjustment. Staff was composed from various institutions dealing with social services provision, but without specialist expertise in demography, urban development and planning. We can hope that the "next" generation of these plans will address issues of shrinking better.

\section{Acknowledgement}

This contribution had been supported by VEGA Grant No. 1/0709/11 „Adaptability of spatial systems during the post-transformation period". 


\section{References:}

Act No. 50/1976 Zb. on Territorial Planning and Building Order (as amended) - in Slovak

Act No. 503/2001 Coll. on Support of Regional Development (as amended by Act No. 539/2008 Coll.) - in Slovak.

Act No. 448/2008 Coll. on Social Services - in Slovak.

BERNT, M. (2009): Partnerships for Demolition: The Governance of Urban Renewal in East Germany's Shrinking Cities. International Journal of Urban and Regional Research, Vol. 33, No. 3, p. 754-769.

BLEHA, B. (2011): Lokálny demografický vývoj na Slovensku: percepcia, spoločenské implikácie a interdisciplinárne výzvy. Sociológia, Vol. 43, No. 4, p. 362-390.

BLEHA, B., BUČEK, J. (2010): Theoretical issues of local population and social policy in 'shrinking' cities - some findings from Bratislava. In: Kovács, Z. [ed]: Challenges of Ageing in Villages and Cities: The Central European Experience. Szeged, Department of Economic and Social Geography, University of Szeged, p. 110-131.

BLEHA, B., VAŇO, B. (2008): Demografická budúcnost’ okresov Slovenska: približovanie či divergencia. Bratislava, Infostat, $82 \mathrm{pp}$.

BUČEK, J. (2005): Slovakia. In: Van Kempen, R., Vermeulen, M. and Baan, A. [eds]: Urban Issues and Urban Policies in the New EU Countries. Aldershot, Ashgate, p. 79-108.

BUČEK, J. (2007): Current strategic economic development planning in cities and its application in Slovakia. Quaestiones Geographicae, 26B, p. 15-25.

BUČEK, J., BLEHA, B. (2012): Planning responses of shrinkage in the Slovak Republic's largest cities. In: Martinez-Fernandez, C., Kubo, N., Noya, A., Weyman, T. [eds.]: Demographic Change and Local Development: Shrinkage, Regeneration and Social Dynamics, OECD Working Papers, Paris, OECD/LEED, p.141-147.

Community Plans of Social Service (2008-2010) as adopted in cities: Banská Bystrica, Košice, Martin, Nitra, Poprad, Prešov, Prievidza, Trenčín, Trnava, Žilina.

FINKA, M., PETRÍKOVÁ D. (2006): Shrinking cities in Central and Eastern Europe. Paper presented at International Symposium - Coping with City Shrinkage and Demographic Change - Lessons from around the Globe, Dresden 3031.03.2006, Germany.

GAJDOŠ, P. (2002): Človek, spoločnost', prostredie - vybrané problémy priestorovej sociológie. Bratislava, Sociologický Ústav $\mathrm{SAV}, 374 \mathrm{pp}$.

GROSSMANN, K., HAASE, A., RINK, D., STEINFÜHRER, A. (2008): Urban shrinkage in East Central Europe? Benefits and limits of a cross-national transfer of research approaches. In: Nowak, M. and Nowosielski, M., [eds.]: Declining cities/ Developing cities: Polish and German perspectives. Poznan, Instytut Zachodni, p. 77-99.

HOLLANDER, J. B., PALLAGST, K. M., SCHWARZ, T., POPPER, F. J. (2009): Planning shrinking cities. Progress in Planning, Vol. 72, No. 4, p. 223-232.

JURČOVÁ, D. et al. (2006): Populačný vývoj v okresoch Slovenskej republiky 2005. Bratislava, Infostat, 118 pp.

KOHLER, H. P., BILLARI, F. C., ORTEGA , J. A. (2002): The emergence of lowest-low fertility in Europe during the 1990s. Population and Development Review, Vol. 28, No. 4, p. 641-680.

MARTINEZ-FERNANDEZ, C. AUDIRAC, I., FOL S., CUNNINGHAM-SABOT, E. (2012): Shrinking Cities: Urban Challenges of Globalization. International Journal of Urban and Regional Research, Vol. 36, No. 2, p. 213-25.

MARTINEZ-FERNANDEZ, C., WEYMAN, T. (2012): The crossroads of demographic change and local development. In: Martinez-Fernandez, C., Kubo, N., Noya, A., Weyman, T. [eds.]: Demographic Change and Local Development: Shrinkage, Regeneration and Social Dynamics. OECD Working Papers, Paris, OECD/LEED, p. 15-37.

MASTER PLANS (2002-2011) as adopted in cities: Bratislava, Nitra, Prešov, Prievidza, Trenčín, Banská Bystrica (proposal).

MATLOVIČ, R., IRA, V., KOREC, P., ONDOŠ, S. (2009): Urban structures and their transformation (the contribution of Slovak geography). Geographia Slovaca, Vol. 26, p.71-100.

MLÁDEK, J. et al. (2006): Population Atlas of Slovakia. Bratislava, Comenius University, 168 pp.

MOSS, T. (2008): „Cold spots“ of urban infrastructure: „Shrinking“ process in Eastern Germany and the modern infrastructure ideal. International Journal of Urban and Regional Research, Vol. 32, No. 2, p. 436-451.

PALLAGST, K. (2010): The planning research agenda: shrinking cities - a challenge for planning cultures. The Town Planning Review, Vol. 81, No. 5, I-VI.

PROGRAMMES OF ECONOMIC AND SOCIAL DEVELOPMENT (2005-2011) as adopted in cities: Banská Bystrica, Bratislava, Košice, Martin, Nitra, Poprad, Prešov, Prievidza, Trenčín, Trnava, Žilina. 
RIENIETS, T. (2009): Shrinking cities: causes and effects of urban population losses in the twentieth century. Nature and Culture, Vol. 4, No. 3, p. 231-254.

RUMPEL, P., SLACH, O. (2012). Je Ostrava „smrštujícím se městem“? Sociologický časopis/Czech Sociological Review, Vol. 48, No. 5, p. 859-878.

SLAVÍK, V. (1998). Územné zmeny obcí v Slovenskej republike v etape transformácie (1990-1998). Acta Facultatis Rerum Naturalium Universitatis Comenianae, No. 41, p. 137-154.

SLAVÍK, V., KOŽUCH, M. (2003): Land use plans - a document of the city in the transformation period. Acta Universitatis Carolinae - Geographica, Vol. 38, No. 1, p. 387-402.

SLAVÍK, V., KOŽUCH, M., BAČÍK, M. (2005): Big cities development in Slovakia: Development, planning, contemporary transformation. European Spatial Research and Policy, Vol. 12, No. 2, p. 47-69.

STATISTICAL OFFICE OF THE SLOVAK REPUBLIC (1996-2010): Population movement statistics. Available at www. statistics.sk.

STEINFÜHRER, A., HAASE, A. (2007): Demographic Change as a Future Challenge for Cities in East Central Europe. Geografiska Annaller, Vol. 89 B, No. 2, p. 183-195.

STEINFÜHRER, A., BIERZYNSKI, A., GROSSMANN, K., HAASE, A., KABISCH, S., KLUSÁČEK, P. (2010): Population Decline in Polish and Czech Cities during Post-socialism? Looking Behind the Official Statistics. Urban Studies, Vol. 47, No. 11, p. 2325-2346.

ŠPROCHA, B. (2008): Reprodukčné správanie mestského a vidieckeho obyvatel’stva na Slovensku. Bratislava, Infostat, 73 pp.

TUROK, I., MYKHNENKO, V. (2007): The trajectories of European cities, 1960-2005. Cities, Vol. 24, No. 3, p. $165-182$.

VEREŠÍK, J. (1974): Mestá. In: Plesník, P. et al.: Slovensko: L’ud (I. čast'). Bratislava, Obzor, p. 522-578.

WIECHMANN, T. (2008): Errors Expected - Aligning Urban Strategy with Demographic Uncertainty in Shrinking Cities. International Planning Studies, Vol. 13, No. 4, p. 431-446.

WIECHMANN, T., PALLAGST, K. (2012): Urban shrinkage in Germany and the USA: A Comparison of Transformation Patterns and Local Strategies. International Journal of Urban and Regional Research, Vol. 36, No. 2, p. 261-80.

WOLF, D. A., AMIRKHANYAN, A. A. (2010): Demographic change and its public sector consequences. Public Administration Review, Vol. 70, Special Issue, p. 512-523.

\section{Authors' addresses:}

Assoc. Prof. Ján BUČEK, e-mail: bucek@fns.uniba.sk Assoc. Prof. Branislav BLEHA, e-mail: bleha@fns.uniba.sk

Department of Human Geography and Demography, Faculty of Natural Sciences

Comenius University, 84215 Bratislava, Slovakia

Initial submission 30 June 2012, final acceptance 10 March, 2013

Please cite this article as:

BUČEK, J., BLEHA, B. (2013): Urban Shrinkage as a Challenge to Local Development Planning in Slovakia. Moravian Geographical Reports, Vol. 21, No. 1, p. 2-15. 